\title{
Novo Visual da Capa
}

Iniciando com o número 1 de 1995, a Revista de Saúde Pública aparece com novo visual, mais moderno no que tange à apresentação de sua capa. Também ocorreu mudança concernente ao formato, que foi aumentado para possibilitar maior arejamento do texto e, conseqüentemente, melhor qualidade na leitura.

Como orientação geral, tem-se observado rápida evolução dos periódicos cientfficos para a modernidade, implicando pois o abandono, cada vez maior, do conservadorismo. $E$ isso tem-se refletido, năo apenas em alterações na apresentação mas, também, em mudanças de título. Este, na medida em que a evolução se processa vai traduzindo o perfil que, progressivamente, a comunidade científica vai impondo ao perí́dico que ela escolhe para divulgar os seus trabalhos. No caso da Revista, é necessário dizer que as contribuições encaminhadas pertencem, em sua maior parte, ao campo de conhecimento da epidemiologia. $E$ tanto de laboratório como de campo, abordando os mais variados temas referentes a diversos agravos à saúde da populaçảo. Esse perfil epidemiológico tem merecido o reconhecimento que ultrapassa os limites nacionais e, dessa forma, a Revista é atualmente considerada como de caráter internacional. A título de exemplificaçāo, recente a publicaçāo da OPS - Epidemiologia básica, 1994 -, em seu anexo 3, elenca as revistas latinoamericanas mais produtivas em epidemiologia, onde se encontra indicada a Revista de Saúde Pública.

Essa progressiva dominância da epidemiologia não impediu, e nem impede, que este periódico seja o veículo de temática de interesse geral para a saúde pública. Dentre elas destacam-se as de cunho administrativo e as referentes à qualidade de vida, consideradas ao nível da populaçảo e da sociedade.

Não há como deixar de aproveitar esta oportunidade de reconhecer que sem a participação de todos aqueles que se empenharam no avanço qualitativo da Revista não estaria hoje escrevendo esta nota. $E$, claro está, que esse agradecimento vai dirigido, com ênfase, àqueles que săo a propria razāo de ser da Revista, os colaboradores que a escolheram como veículo para divulgação de seus trabalhos científicos. 